JOURNAL OF AWARENESS

$\int_{\substack{\text { RATIN } \\ \text { ACADEM }}} \frac{E-I S S N: 2149-6544}{\text { Cilt:3, Sayl:3, Temmuz 2018 Vol:3, Issue:3, July 2018 }}$

http://www.ratingacademy.com.tr/ojs/index.php/joa

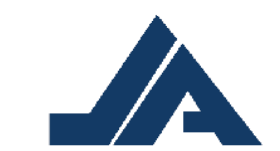

JOURNAL OF AWARENES

\title{
COMPARISON NUMBERS OF PHOTOGRAPH USED IN PRINTED AND INTERNET NEWSPAPERS OF THREE BEST-SELLING NEWSPAPERS IN SEVEN DAILY PERIOD
}

Burak ACAR

Sakarya University Communication Study and Media Master Programme Student

Sakarya/TURKEY, e-Mail: acarburak22@gmail.com

Bedriye TAYLI

Selçuk University Public Relations PhD Student, Konya/TURKEY

\begin{tabular}{|c|c|}
\hline ARTICLE INFO & ABSTRACT \\
\hline $\begin{array}{l}\text { Article History: } \\
\text { Received: 9 May } 2018 \\
\text { Accepted: } 20 \text { July } 2018\end{array}$ & \multirow{3}{*}{$\begin{array}{l}\text { With the development of technology, the traditional media has begun to leave its } \\
\text { place to digital atmosphere. Along with the use of digital media, people began to } \\
\text { focus on visual materials rather than written texts. In this age when people have } \\
\text { shown a lot of interest in visual materials, the photo has entered a new phase. } \\
\text { Perhaps the photo has begun to show more interest than ever before. Because, } \\
\text { photography is an indispensable part of digital media. Actually, we use } \\
\text { photography not only in digital media, but almost in all areas of our lives. } \\
\text { Photographs used in the media can clearly show many things the journalist does } \\
\text { not write in the news text. In addition, photographs are seen as the most } \\
\text { important document of the written news. In today's world where people attach } \\
\text { more importance to visual rather than written texts, we can see that the usage of } \\
\text { photography is so great that it is underestimated in both printed and internet } \\
\text { newspapers. In this study, news photographs used as visual material in both } \\
\text { printed and internet newspapers was analyzed by the method of semiotics. } \\
\text { Photographs used in printed and internet newspapers for a week was examined } \\
\text { and recorded. Then, by determining in which area the photos are used more } \\
\text { often, their causes was discussed. }\end{array}$} \\
\hline $\begin{array}{l}\text { Keywords: photography, } \\
\text { printed and internet } \\
\text { newspapers, digital media }\end{array}$ & \\
\hline $\begin{array}{l}\text { DOI: } \\
\text { 10.26809/joa.2018342292 }\end{array}$ & \\
\hline
\end{tabular}

\section{INTRODUCTION}

Seeing comes before words. The child looks and recognizes before it can speak (Berger, 1972). According to Berger, human beings know and learn from their birth by seeing their surroundings and everything. When we hear something, we immediately want to see what we hear, and we usually prefer to believe after we see it. Therefore, contrary to the traditional media, the visual elements in the new media are more preliminary. 
Photographs, which fiddle with the scale of the world, themselves get reduced, blown up, cropped, retouched, doctored, tricked out. They age, plagued by the usual ills of paper objects; they disappear; they become valuable, and get bought and sold; they are reproduced. Photographs, which package the world, see to invite packaging. They are stuck in albums, framed and set on tables, tacked on walls, projected as slides. Newspapers and magazines feature them; cops alphabetize them; museum's exhibit them; publishers compile them (Sontag, S. 1977).

When we look at the past from day to day, we can say that we are not surrounded by so many visuals. The main reasons for the fact that images are so much in our lives are the rapid development of technology, the widespread use of mass media, and the fact that smart phones take up too much in our lives. Of course, these visual objects surrounding our lives did not only affect the people, they influenced the printed media which is one of the mass media.

The Internet is a globally interactive environment, enabling users to access online newspapers from anywhere in the world. The Internet transforms the world into a smaller place than the world by providing instant access to users who happen to be in any part of the world without the time and space limitations. (Williams, 2003).

With the widespread use of the Internet, a new type of journalism has emerged that broadcasts on the Internet, which is also presented as an alternative media. This new genre is called electronic publishing in general terms, internet journalism in a more specific term (Çakır, 2007). The biggest advantage of the internet as new and alternative media is the opening of new gateways for free information acquisition. As you can access any kind of information instantly on the internet, you can reach the information you want more quickly. It is also an interactive publishing with reader/viewer on the internet. The user can express and comment on the feelings and thoughts related to the news he reads. It is not a one-sided communication. The fact that one-to-one communication can be accessed instantly and interactively, the contents can be renewed at any time and the news can be updated at any time reveal the differences of internet journalism from other mass media. Individuals, especially the individuals in the connection, have unrestricted and easy access to alternative channels of information (Yedig, \& Akman, 2002).

A new type of journalism has emerged today, which is referred to as internet journalism, by the spread of individual and social heritage, the formation of public opinion and the use of the internet in addition to the traditional types of newspapers, which are the first place to collect historical information as raw materials (Gezgin, 2002). Unlike traditional media, Internet journalism has four aspects that are most prominent: speed, being able to be reversible, allowing details, and emancipating from the point of view of the publisher and of the reader (Dilmen, 2005).

With the new developments that have surfaced with the Internet, contents such as sound, moving picture, text and picture have come to be portable (Atabek, 2003). While the use of text and photographs is proportional to the traditional printed news, we see that the photographs are heavily used in today's news. Especially with the new media, we can say that the photographs are more dominant than the ones used as an element to be used beside the texts in printed media. With the new media, it is now seen that photographs have given priority to texts in news presentations. With this change, the photographs have become a more prominent position than the news texts. At the same time, the fact that the problem of space on the page has been removed in the internet environment causes the increase of the number of visual elements used in the news. Thus, with the development of new media, the use of visual elements, especially photography, is limited due to the limited space in printed pages, 
and the use of visual elements in online newspapers is almost limitless. This study aims to reveal the difference between the number of photographs used in online journalism and the number of photographs used in written journalism by comparing the numbers of photograph usage in written and internet journalism and to reveal the reasons of this difference.

The development of internet technology has brought a new breath to journalism. But this technology has had positive effects on traditional journalism as well as adverse effects. In the process of transformations in terms of journalism, while maintaining the existence of traditional newspapers, on the other hand online newspapers continue to secure indispensable places in society. It is predicted that the printed newspapers will be totally destroyed, the journalistic practices will change with the new media, and citizen journalism will gain weight. Therefore, online journalism emerges as an important field that needs to be examined in terms of journalism.

\section{METHOD}

In the study, printed newspapers and internet newspapers were compared and it was searched to see how much the pictures used in internet journalism were used compared to written newspapers. For this purpose, content analysis method was used for data collection. In order to limit the scope of the research, the 7-day periods of Hürriyet, Sabah and Sözcü, the three bestselling newspapers in Turkey, were discussed. The number of photographs used on the internet newspapers and in the printed newspapers was evaluated within the scope of the first page, agenda, world, economy and sports titles.

\section{FINDINGS AND COMMENTS}

Hürriyet, Sabah and Sözcü newspapers, which continue to be published daily and national newspapers, have 3 circulation newspapers with the highest circulation according to the data of http://gazetetirajlari.com/2017/04/17/.

Table 1. Number of Photos Used in Hürriyet Newspaper

\begin{tabular}{cccccccccc}
\multicolumn{2}{c}{ First Page } & \multicolumn{2}{c}{ Agenda } & \multicolumn{2}{c}{ World } & Economy & Sport \\
\hline Printed & Online & Printed & Online & Printed & Online & Printed & Online & Printed & Online \\
Newspa & Newspa & Newspa & Newspa & Newspa & Newspa & Newspa & Newspa & Newspa & Newsp \\
per & per & per & per & per & per & per & per & per & aper
\end{tabular}

\begin{tabular}{|c|c|c|c|c|c|c|c|c|c|c|c|}
\hline 1 & $\begin{array}{c}10.04 \\
2107\end{array}$ & 22 & 121 & 38 & 64 & 12 & 30 & 27 & 40 & 38 & 202 \\
\hline 2 & $\begin{array}{c}11.04 \\
2107\end{array}$ & 18 & 115 & 55 & 81 & 9 & 19 & 30 & 48 & 37 & 142 \\
\hline 3 & $\begin{array}{c}12.04 . \\
2107\end{array}$ & 18 & 107 & 69 & 79 & 10 & 25 & 21 & 46 & 29 & 153 \\
\hline 4 & $\begin{array}{c}13.04 . \\
2107\end{array}$ & 26 & 102 & 56 & 45 & 12 & 53 & 31 & 75 & 27 & 197 \\
\hline 5 & $\begin{array}{c}14.04 . \\
2107\end{array}$ & 15 & 109 & 54 & 67 & 19 & 51 & 21 & 59 & 34 & 149 \\
\hline 6 & $\begin{array}{c}15.04 \\
2107\end{array}$ & 24 & 105 & 75 & 56 & 8 & 17 & 16 & 45 & 29 & 147 \\
\hline 7 & $\begin{array}{c}16.04 \\
2107\end{array}$ & 17 & 114 & 68 & 105 & 11 & 24 & 14 & 39 & 31 & 151 \\
\hline & Total & 140 & 773 & 415 & 497 & 81 & 219 & 160 & 352 & 225 & 1141 \\
\hline
\end{tabular}


ACAR \& TAYLI / Comparison Numbers of Photograph Used in Printed and Internet Newspapers of Three Best-Selling Newspapers in Seven Daily Period

Table 2. Number of Photos Used in Sabah Newspaper

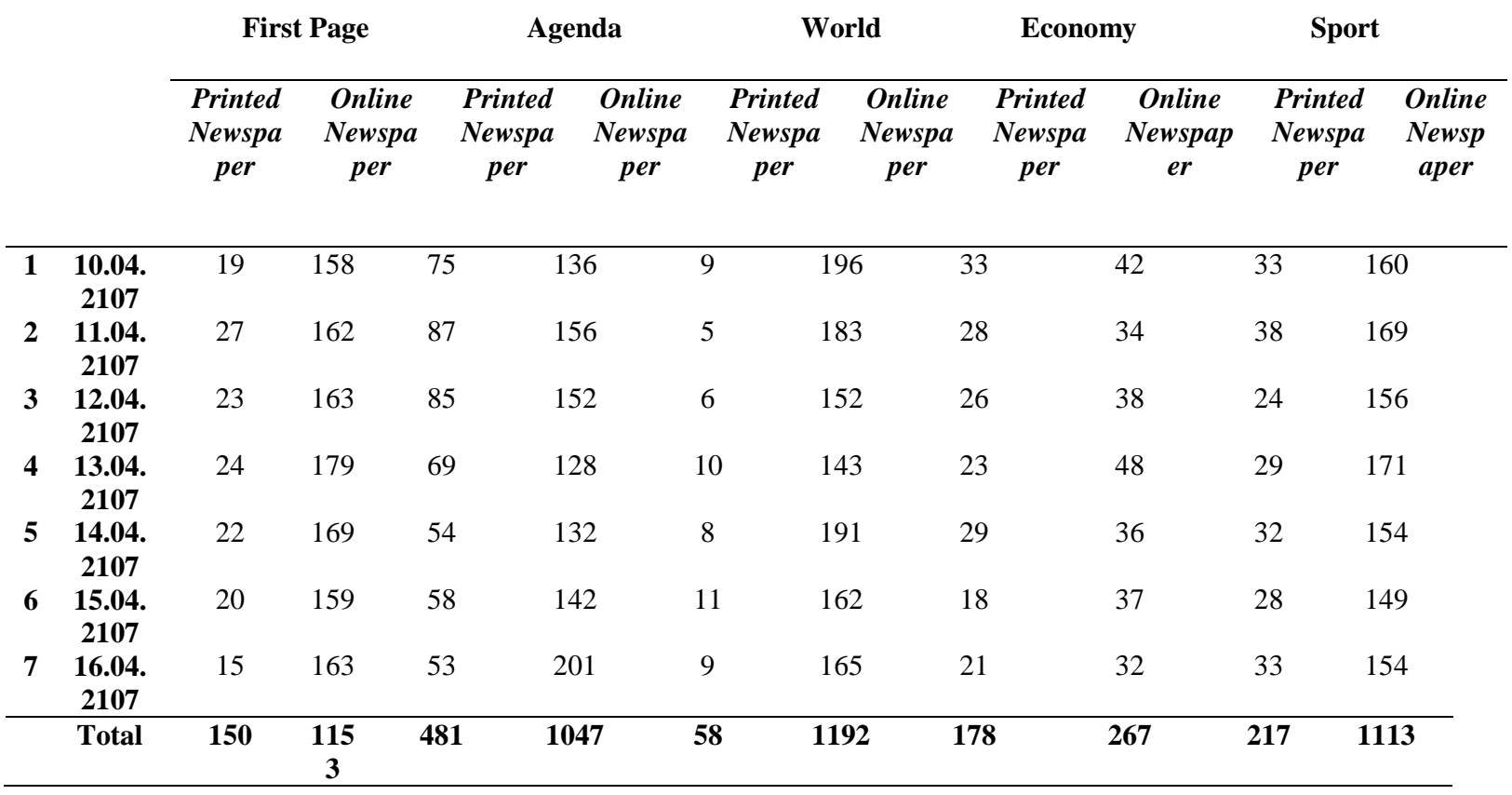

Table 3. Number of Photos Used in Sözcü Newspaper

\begin{tabular}{|c|c|c|c|c|c|c|c|c|c|c|c|c|}
\hline & & \multicolumn{3}{|c|}{ First Page } & \multicolumn{2}{|c|}{ Agenda } & \multicolumn{2}{|c|}{ World } & \multicolumn{2}{|c|}{ Economy } & \multicolumn{2}{|c|}{ Sport } \\
\hline & & $\begin{array}{c}\text { Printed } \\
\text { Newspape } \\
r\end{array}$ & & & $\begin{array}{c}\text { Printed } \\
\text { Newspa } \\
\text { per }\end{array}$ & $\begin{array}{c}\text { Online } \\
\text { Newspa } \\
\text { per }\end{array}$ & $\begin{array}{c}\text { Printed } \\
\text { Newspa } \\
\text { per }\end{array}$ & $\begin{array}{c}\text { Online } \\
\text { Newspa } \\
\text { per }\end{array}$ & $\begin{array}{c}\text { Printed } \\
\text { Newspa } \\
\text { per }\end{array}$ & $\begin{array}{c}\text { Online } \\
\text { Newspap } \\
\text { er }\end{array}$ & $\begin{array}{c}\text { Printed } \\
\text { Newspa } \\
\text { per }\end{array}$ & $\begin{array}{c}\text { Online } \\
\text { Newsp } \\
\text { aper }\end{array}$ \\
\hline 1 & $\begin{array}{c}10.04 \\
2107\end{array}$ & 18 & 123 & 53 & & 82 & 16 & 68 & 27 & 29 & 30 & 112 \\
\hline 2 & $\begin{array}{c}11.04 . \\
2107\end{array}$ & 18 & 118 & 61 & & 79 & 8 & 36 & 21 & 26 & 26 & 109 \\
\hline 3 & $\begin{array}{c}12.04 \\
2107\end{array}$ & 20 & 117 & 47 & & 74 & 5 & 22 & 15 & 25 & 20 & 105 \\
\hline 4 & $\begin{array}{c}13.04 \\
2107\end{array}$ & 15 & 112 & 42 & & 67 & 8 & 26 & 17 & 27 & 22 & 153 \\
\hline 5 & $\begin{array}{c}14.04 \\
2107\end{array}$ & 18 & 114 & 54 & & 77 & 7 & 34 & 19 & 28 & 26 & 106 \\
\hline 6 & $\begin{array}{c}15.04 \\
2107\end{array}$ & 18 & 113 & 59 & & 74 & 6 & 29 & 18 & 26 & 22 & 104 \\
\hline \multirow[t]{2}{*}{7} & $\begin{array}{c}16.04 \\
2107\end{array}$ & 17 & 121 & 56 & & 114 & 8 & 32 & 16 & 27 & 24 & 107 \\
\hline & Total & 124 & 818 & 372 & & 567 & 58 & 247 & 133 & 188 & 170 & 796 \\
\hline
\end{tabular}




\subsection{Photos used on the First Page}

When looking at the number of photographs used on the first page of the newspapers, it is seen that Sabah newspaper is the most used newspaper in print (150 photographs) and Internet newspaper (1153 photographs), as seen in Table 2.

As can see Table 1, Sabah newspaper was followed by Hurriyet newspaper with 140 photos in printed newspaper and 124 photos in Table 3 were published on the first page of Sözcü newspaper. When we look at the number of photographs used by online newspapers, it is seen in Table 1 and 3 that the Sözcü newspaper uses 818 photographs and the Hürriyet newspaper uses 773 photographs.

\subsection{Photos used on the Agenda}

When looking at the photographs used under the heading of the agenda, we can say that the Sabah newspaper is the newspaper that used the most photographs in the printed media (481 photographs) and online media (1047 photographs), as seen in table 2. Moreover, when looking at Table 2 again, we can clearly say that there is a considerable difference in the number of photographs (566 photographs) used between written and online newspapers. As can see Table 1, Sabah newspaper was followed by Hurriyet newspaper with 415 photos in printed newspaper and 372 photos in Table 3 were published on the first page of Sözcü newspaper. When we look at the number of photographs used by online newspapers, it is seen in Table 1 and 3 that the Sözcü newspaper uses 567 photographs and the Hürriyet newspaper uses 497 photographs.

\subsection{Photos used on the World}

When looking at the numbers of photographs used under the world title, it is seen that in the printed media, 81 photographs are seen in the Hürriyet newspaper, as seen in table 1. It is seen in Table 2 and 3, in the printed media, Hürriyet newspaper was followed by 58 photographs Sabah and Sözcü newspapers. When we look at the numbers of photographs used in online newspapers, we can see that Sabah newspaper used 1192 photographs, Sözcü newspaper used 247 photographs and 219 photographs are used in the Hürriyet newspaper. Additionally, it can be said that the difference between the number of the photographs used in printed and online newspapers under the world title is at most 1134 photographs in the Sabah newspaper as seen in Table 2.

\subsection{Photos used on the Economy}

When looking at the numbers of photographs used under the Economy title, it is seen that in the printed media, 178 photographs are seen in the Sabah newspaper, as seen in table 2. It is seen in Table 1 and 3 that the Hürriyet newspaper uses 160 photographs and the Sözcü newspaper uses 133 photographs in the printed media. In online newspapers, under the title of economy, most of them are used in the Hürriyet newspaper (352 photographs) as seen in the photograph table 1, this number is followed by 178 photographs Sabah newspaper and 133 photographs Sözcü newspaper, it is seen in Table 2 and 3.

\subsection{Photos used on the Sport}

When lookinng at the number of photographs used on the Sport title of the newspapers, it is seen that Hürriyet newspaper is the most used newspaper in print (225 photographs) and Internet newspaper (1141photographs), as seen in Table 1. As can see Table 2, Hürriyet newspaper was followed by Sabah newspaper with 217 photos in printed newspaper and 170 photos in Table 3 were published on the Sport title of Sözcü newspaper. When we look at the number of photographs used by online newspapers, it is seen in Table 2 
and 3 that the Sabah newspaper uses 1113 photographs and the Sözcü newspaper uses 796 photographs under sport title.

Table 4. Total number of printed and online photographs of newspapers

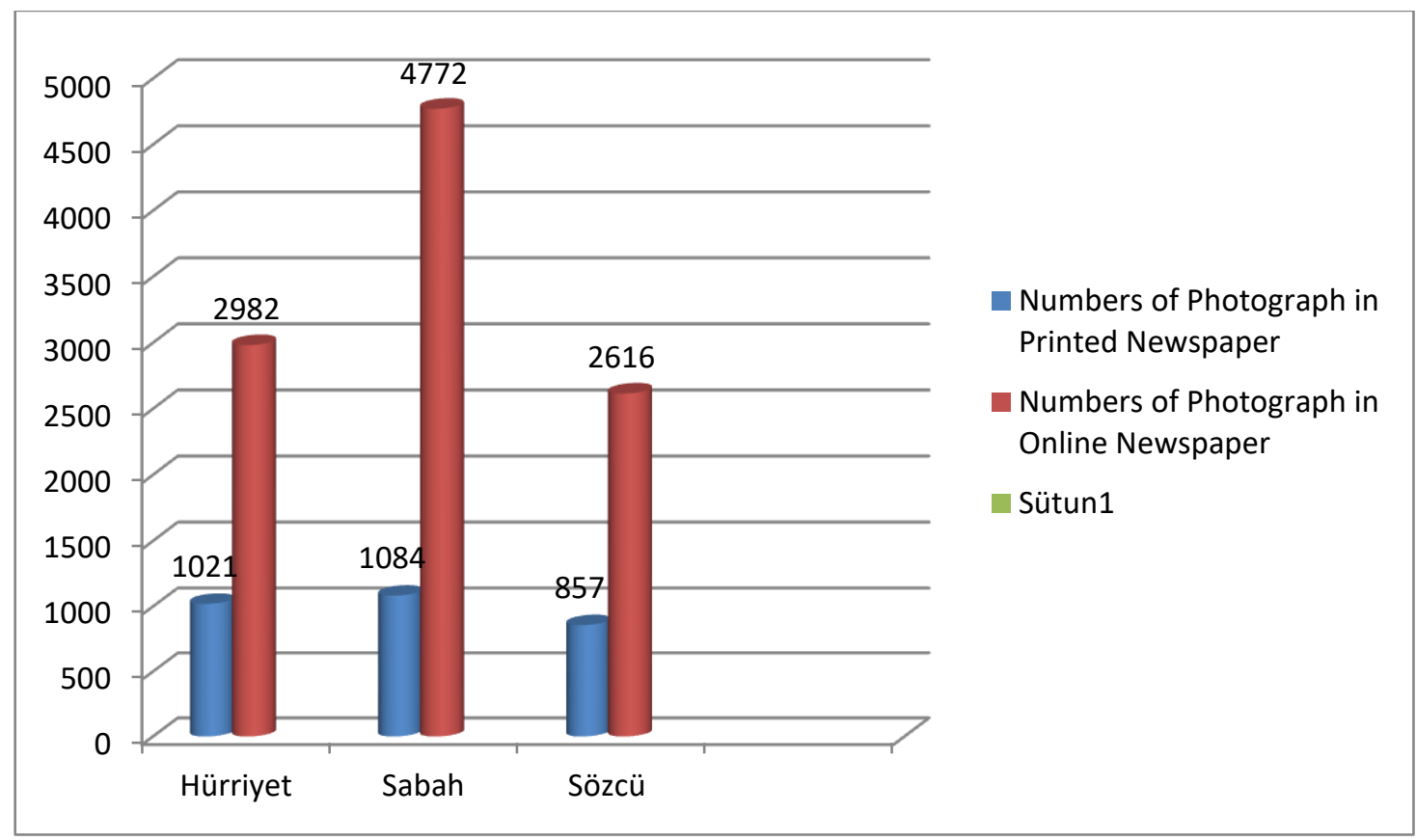

When examined table 4, it is seen that most of the photographs (5856 photographs) are used in Sabah newspaper both in printed newspapers (1084 photographs) and in online newspapers (4772 photographs). It is determined in Hürriyet newspaper that while using 1021 photographs in printed newspapers, it was used 2982 photographs in online journal and 4003 photographs was used in total. In the Sözcü newspaper, it was determined that while using 857 photographs in printed newspapers, 2616 photographs were used in online journal and 3473 photographs were used in total.

\section{CONCLUSIONS}

There are radical changes in the media with new communication technologies and this process is continuing rapidly. The newspapers at the head of the traditional media are the media organizations most affected by this change. Newspapers continue to keep up with new developments and continue their publishing lives, utilize the possibilities offered by the internet to reach more readers. The Hürriyet, Sabah and Sözcü newspapers that it has been selected as examples in the study are the highest circulation newspapers in Turkey. In addition, it can be said that these websites are the most visited sites in Turkey.

When the photos of Hürriyet, Sabah and Sözcü newspapers are compared on the first page, agenda, world, economy and sports titles in the internet pages and printed newspapers in the 7-day period, it is seen that the number of the photographs on the internet page are quantitatively ahead of the printed newspapers.

During the period examined, there were 145 photographs on average per day in the printed journal of the Hürriyet newspaper, while 426 pictures were published on the internet page. While 681 photos were published on the internet page of Sabah newspaper, there were 154 photographs on average per day in the printed journal. In the printed newspaper of the 
Sözcü newspaper, on average 122 photographs were taken place, while 373 photographs were published on the internet page.

Within the 7 day period, in total, there were 1021 photographs in the printed journal, 2982 photographs in the internet newspaper of the Hürriyet newspaper; There were 1084 photographs in the printed newspaper, 4772 photographs in the internet newspaper; of the Sabah newspaper; In the Sözcü newspaper, there were 857 photographs in the printed newspaper and 2616 photographs in the internet newspaper. This shows that the internet newspaper is richer in terms of visual material than the printed newspaper. It turns out that the internet environment known as multimedia is giving more importance to the photo.

As a result, because of the lack of space in the internet newspaper, the use of photography is much higher than in printed newspapers. Moreover, as people today prefer the virtual environment to follow-up news, the circulation of printed newspapers falls day by day. In the face of this decrease in printed newspapers, newspapers have started to give importance to internet journalism. It is clear that digital media will be more common and effective in the coming years than traditional media. 


\section{REFERENCES}

ATABEK, Ü. (2003). İletişim Teknolojileri ve Yerel Medya İçin Olanaklar. Yeni iletişim teknolojileri ve medya.

BERGER, J. (1972). Ways of Seeing. Ways of Seeing, 50, 249-259.

ÇAKIR, H. (2007). Geleneksel Gazetecilik Karşısında İnternet Gazeteciliği.

DİLMEN, N. E. (2005). Yönetenler Açısından Türkiye'deki İnternet Gazeteleri ve Haber Portalları Üzerine Bir Değerlendirme. İstanbul Üniversitesi İletişim Fakültesi Dergisi.

GEZGİN, S. (2002). Geleneksel Basın ve İnternet Gazeteciliği. İnternet Çağında Gazetecilik.

SONTAG, S. (1977). On photography. Macmillan.

YEDİG, S., \& AKMAN, H. (2002). İnternet çağında gazetecilik. Siyahbeyaz yayınları, İstanbul.Gezgin, Suat (2002). "Geleneksel Basın ve İnternet Gazeteciliği”"

WILLIAMS, K. (2003). Understanding media theory.

http://gazetetirajlari.com/2017/04/17/

http://www.hurriyet.com.tr/

http://www.sabah.com.tr/

http://www.sozcu.com.tr 